\title{
Length Based Growth Estimation of Sea Cucumbers (Holothuria verrucosa and Holothuria pardalis) (Holothuroidea:Echinodermata) Collected from Coastal Areas of Karachi, Pakistan (northern Arabian Sea)
}

\author{
Quratulan AHMED ${ }^{1} \quad$ Sabri BILGIN ${ }^{*} \quad$ Qadeer Mohammad ALI $^{1}$ \\ ${ }^{1}$ The Marine Reference Collection and Resource Centre, University of Karachi, Karachi, Pakistan. \\ ${ }^{2}$ University of Sinop, Fisheries Faculty, Department of Fisheries, Sinop, Turkey.
}

How to cite: Ahmed, Q., Bilgin, S. \& Ali, Q.M. (2020). Length based growth estimation of sea cucumbers (Holothuria verrucosa and Holothuria pardalis) (Holothuroidea:Echinodermata) collected from coastal areas of Karachi, Pakistan (northern Arabian sea). J. Anatolian Env. and Anim. Sciences, 5(3), $382-389$. Atıf yapmak için: Ahmed, Q., Bilgin, S. \& Ali, Q.M. (2020). Arap Denizinde (Pakistan) Deniz Hıyarlarının (Holothuria verrucosa and Holothuria pardalis) (Holothuroidea: Echinodermata) büyümesinin boya dayalı tahmini. Anadolu Çev. ve Hay. Dergisi, 5(3), 382-389.

: https://orcid.org/0000-0003-0155-8981 (iD) : https://orcid.org/0000-0002-7597-2483 iD: https://orcid.org/0000-0002-0499-0801
*Corresponding author's: Sabri BíLGiN

University of Sinop, Fisheries Faculty, Department of Fisheries, Sinop, Turkey. $\triangle$ : sbrbilgin@hotmail.com

Telephone : +90(368) $2876254(3391$ Fax $\quad:+90(368) 2876269$
Abstract: Non-seasonal von Bertalanffy and Hoenig seasonal von Bertalanffy models were fitted to the length frequency data of Holothuria pardalis and Holothuria verucosa sampled from the coastal areas of Karachi between January and December 2018 for estimating the growth parameters. The Hoenig seasonal von Bertalanffy growth parameters were estimated as $L_{\infty}=18.0$ cm total length (TL), $K=1.00$ year $^{-1}$ for $H$. pardalis and as $L_{\infty}=18.0 \mathrm{~cm} \mathrm{TL,} K=0.86$ year $^{-1}$ for $H$. verrucosa. $H$. verrucosa individuals reached $68.9 \%$ of their maximum total length at the one year old age class. For $H$. pardalis it was calculated as $54.2 \%$. The seasonal oscillation in growth rate for $H$. pardalis $(C=0.90)$ was larger than it was for $H$. verrucosa $(C=0.18)$. The slowest period of growth corresponded to June in $H$. verrucosa and February in $H$. pardalis may be the result of the extended both reproduction and poor nutrition periods due to high rainfall regime. The relatively high calculated values of growth rate parameters for both species may have an important state for their survival rate under the condition of biological stress, but may also increase their potential as a candidate species for aquaculture.

Keywords: Biological stress, growth estimation, sea cucumber, seasonal oscillation, north Arabian Sea.

\section{Arap Denizinde (Karachi, Pakistan) Deniz Hıyarlarının (Holothuria verrucosa ve Holothuria pardalis) (Holothuroidea: Echinodermata) Büyümesinin Boya Dayalı Tahmini}

\section{*Sorumlu yazar:}

Sabri BILGGiN

Sinop Üniversitesi, Su Ürünleri Fakültesi,

Avlamave İșleme Teknolojisi Bölümü,

Sinop, Türkiye.

\: sbrbilgin@hotmail.com

Telephone : $+90+90(368) 2876254(3391$

Faks : : $+90(368) 2876269$
Öz: Arap denizi Karachi sahilerinden Ocak ve Aralık 2018 tarihleri arasında örneklenen iki deniz hıyarının boy-frekans verileri kullanılarak mevsisel olmayan von Bertalanffy ve Hoenig mevsimsel von Bertalanffy büyüme denklemi parametreleri belirlenmiştir. Hoenig denklemi parametreleri Holothuria pardalis için $L_{\infty}=18,0 \mathrm{~cm}$ toplam boy (TL), $K=1,00 \mathrm{yll}^{-1}$, Holothuria

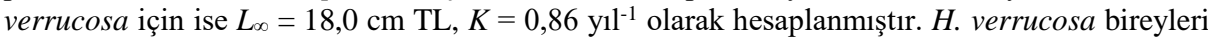
maksimum boyunun \%68,9'una, $H$. verrucosa bireyleri ise maksimum boyunun \%52,4'üne bir yaşında ulaşmıştır. $H$. pardalis $(C=0,90)$ türünün büyüme hızındaki mevsimsel salınım değeri $H$. verrucosa $(C=0,18)$ türünden daha büyük hesaplanmıştır. Hem $H$. verrucosa (haziran) hem de $H$. pardalis (şubat) için büyümenin en yavaş olduğu zaman dilimi, üreme faaliyetlerinin gerçekleştiği ve yükssek yağıș rejiminden dolayı besin madde miktarının azaldığı zaman dilimine karşılık gelmiştir. Araştırma bölgesinde, üreme faaliyetleriyle beraber muson yağmurlarının büyüme üzerine etkisi detaylı bir şekilde çalışılmalıdır Çalışılan türlerin yüksek büyüme oranına sahip olmas, biyolojik olarak strese neden olan ortamlarda hayatta kalmaları ve su ürünleri yetiştiriciliğine aday olma potansiyelerini de artırabilir.

Anahtar kelimeler: Büyüme, biyolojik stres, deniz hıyarı, kuzey Arap denizi, mevsimsel salınım. 


\section{INTRODUCTION}

Sea cucumbers belong to the class Holothuroidea and so are also referred to as holothurians. Holothurians are found throughout all oceans and seas, at all latitudes, from the shore down to abyssal plains (Purcell et al., 2012). The adult stages are benthic (living on the sea bottom); some species live on hard substrates, rocks, coral reefs. Most of the species inhabit soft bottoms, on the sediment surface or buried in the sediment (Purcell et al., 2012; WoRMS, 2020). Holothurian species such as Holothuria pardalis and Holothuria verrucosa is commercially important, distributed at some localities in the Western Pacific, parts of Asia and the Indian Ocean, including the Red Sea and the Comoros, and along the Pacific coast of Central America (Purcell et al., 2012; WoRMS, 2020). This species live in rocky, sandy and muddy bottoms from shallow to deeper waters (Pawson, 1976), and also in crevice between boulders (Ahmed et al., 2020). According to Lane et al. (2000), H. pardalis and $H$ verrucosa live up to $306 \mathrm{~m}$ and $30 \mathrm{~m}$ water depth, respectively.

Total 25 sea cucumber species have been recorded from coastal waters of Pakistan, seven of which are important commercially (Tahera \& Tirmizi, 1995; Purcell, 2010; Purcell et al., 2015; Ahmed \& Ali, 2014; Ahmed et al., 2016a; Ahmed et al., 2020). Currently, sea cucumber fishing occurs all over the world, but, there is no traditional sea cucumber fisheries in Pakistan (Moazzam \& Moazzam 2020).

Knowledge on fisheries biology and population dynamics of marine fauna such as sea cucumbers is important tools for marine biologist. Thus, the crucial biological information including reproduction biology and growth parameters on the commercially important species is necessary for management of global sea cucumbers fisheries. In the scientific literature, there are some works about the growth of sea cucumbers; including the weight length relationships (WLRs) and condition factor (CF) based growth features have been reported in Holothurian species such as Ohshimella ehrenbergii, $H$. arenicola, $H$. atra, $H$. pardalis and $H$. verrucosa from the northern Arabian Sea coasts of Pakistan (Siddique et al., 2014; Ahmed et al., 2018a,b). In addition to these, a detailed study on the population dynamics of sea cucumbers has been carried out on the $H$. arenicola stocks in Manora and Buleji rocky shores in the northern Arabian Sea, Pakistan so far (Siddique \& Ayub, 2015).

The growth parameters can be use as a tool in stock assessment studies, fish biology, fish population dynamics and also fisheries research studies. von Bertalanffy growth function curve parameters mostly effect by biotic and a-biotic factors such as sea water temperature, salinity, primer and/or secondary productivity as phyto and zoo plankton abundance, reproduction and/or spawning time or spawning season, food and feeding activities etc. These parameters under the influence of different factors such as animal size and age, gonad activities and maturity stages, quantitative and quality of food and feeding activities and also seasons etc. In Pakistan, monsoon winds carry moisture from the Indian Ocean and bring heavy rains during the monsoonal period between May and September. More than fifty percent of annual rainfall occurs in the monsoon season, mostly from July to August (Hussaina et al., 2010). Mobilized sea life by pre and post monsoon seasons affect directly or indirectly to the life of marine flora and also fauna species such as sea cucumber, $H$. pardalis and $H$. verrucosa. In the scientific literature, there is no knowledge on seasonal and/or non-seasonal growth parameters of $H$. pardalis and $H$. verrucosa. Our aim was to obtain first growth parameters from length-frequency data of the two species, $H$. pardalis and $H$. verrucosa, inhabiting the Sunehri and Buleji coast (north Arabian Sea, Pakistan), by fitting different growth models: the non-seasonal von Bertalanffy and the Hoenig seasonal von Bertalanffy models.

\section{MATERIAL AND METHOD}

Study area and sampling: Holothuria pardalis (n = 340) and Holothuria verrucosa $(\mathrm{n}=300)$ specimens (Figure1) were monthly collected from Buleji (245' $20.41^{\prime \prime}$ N, 66 $49^{\prime} 24.15^{\prime \prime}$ E) and Sunehri (245' $33.49^{\prime \prime} \mathrm{N}, 6^{\circ} 40^{\prime} 40.20^{\prime \prime} \mathrm{E}$ ) (Figure 2) coast from intertidal zone by hand-picking through forceps at low tide between January to December 2018.

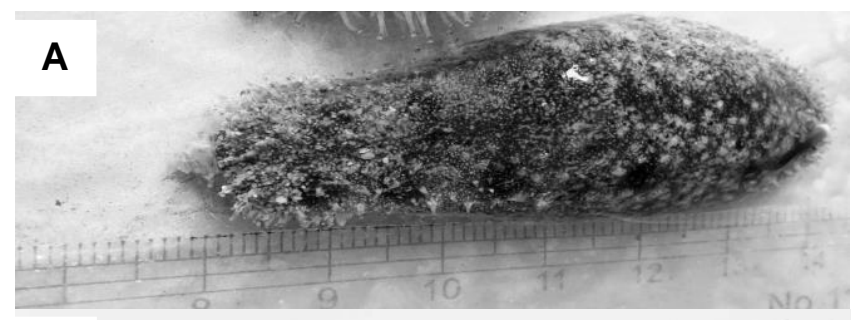

B

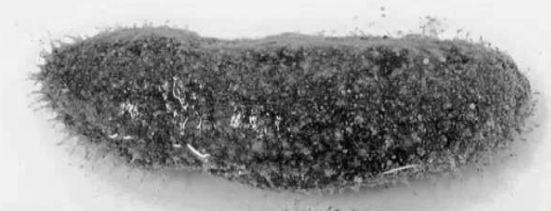

Figure 1. Holothuria pardalis Selenka, 1867 (A) and Holothuria verrucosa Selenka, 1867 (B) Photo by Q. Ahmed.

Collected specimens were kept alive in water filled containers and than were transported to the laboratory and shifted in well aerated aquaria. For taxonomic studies and identification, morphological 
features were examined and microscopic studies were conducted. Ossicles were taken from three positions (dorsal and ventral body walls, and tentacles); wet mounts were prepared by placing a small piece of skin tissue on slide and adding few drops of $3.5 \%$ bleach, the slides were then rinsed with drops of distilled water. The slides were examined under the Nikon LABOPHOT-2 microscope at 10x10 magnifications. Microphotography was also performed through Fujifilm 16 MP digital camera (see Ahmed et al., 2018b for more details). Length $(\mathrm{cm})$ data were collected for each sea cucumber after allowing the sea cucumber to relax in water for $5 \mathrm{~min}$. Total length from mouth to anus was measured to the flexible ruler.

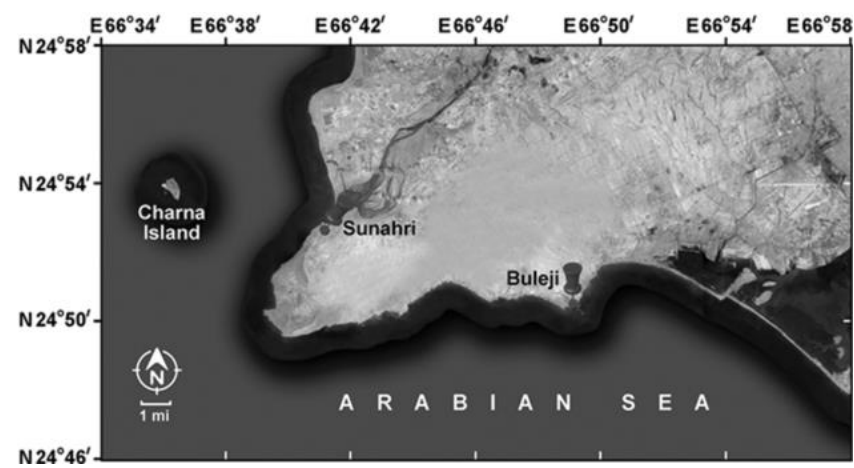

Figure 2. Sampling stations, Buleji and Sunehri in Karachi coast, north Arabian Sea, Pakistan.

Von Bertalanffy Growth Function Parameter

Estimation: Growth in length has been described using the von Bertalanffy (1938) growth function, based on either observed or back calculated length at ages. The length frequency distribution analysis (LFDA) package is also a PC based computer package for estimating growth parameters from length frequency distributions. Version 5.0 of LFDA includes methods for estimating the parameters of both non seasonal and seasonal versions of the von Bertalanffy growth curve (Kirkwood et al., 2003).

The standard (three parameters) or non-seasonal von Bertalanffy (1938) growth function (VBGF) is:

$$
L_{t}=L_{\infty}\left(1-e^{-k\left(t-t_{0}\right)}\right)
$$

Seasonal growth or five parameter von Bertalanffy growth model (5 Parameters VBGF) was described using the Somers's (1988) version of the VBG equation:

$$
\left.L_{t}=L_{\infty}\left[1-e^{\left[-K\left(t-t_{o}\right)-\left(C \frac{K}{2 \pi}\right) \sin 2 \pi\left(t-t_{S}\right)+\left(C \frac{K}{2 \pi}\right) \sin 2 \pi\left(t_{o}-t_{S}\right)\right.}\right]\right],
$$

where, $L_{t}$ is length at age t, $L_{\infty}$ is the asymptotic length to which the sea cucumber growth, $K$ is the growthrate parameter, $t_{0}$ is the nominal age at which the length is zero, $C$ is the relative amplitude $(0 \leq \mathrm{C} \leq 1)$ of the seasonal oscillations, $t_{S}$ is the phase of the seasonal oscillations $(-0.5$ $\leq$ ts $\leq 0.5$ ) denoting the time of year corresponding to the start of the convex segment of sinusoidal oscillation.
The time of the year when the growth rate is slowest, known as the winter point $(W P)$, was calculated as:

$W P=t_{S}+0.5$.

Seasonal VBG curves were fitted to the length distributions after first indicating a range of values of $L_{\infty}$ and $K$ and reducing iteratively the range to maximize the goodness of fit $(R n)$ of the curves to the data. $R n$ was calculated as:

$$
R n=\frac{10^{\frac{E S P}{A S P}}}{10},
$$

where $A S P$ is the available sum of peaks, computed by adding the best values of the available peaks, and ESP is the explained sum of peaks, computed by summing all the peaks and troughs hit by the VBGF curve.

Analysis of the length data were fitted to length frequency distributions grouped in $2 \mathrm{~cm}$ total length size classes using the electronic length frequency analysis (ELEFAN) procedure in the PC-based computer package Version 5.0 of Length - Frequency Distribution Analysis (Kirkwood et al. 2003).

The ELEFAN procedure first restructures length frequencies and than fits a VBGF curve to the restructured data. Both seasonal and non-seasonal VBGF curves were fitted to the seasonal length distribution after providing a range of values for the parameters to be estimated and than iteratively reducing the range until the goodness of fit of the curve to the data is maximized.

Reliability of growth parameter estimates: Having estimated a set of growth parameters, one would like to evaluate their reliability. A possible test is the socalled phi-prime test ( $\left.\Phi^{\prime}\right)$ known as growth performance index. This test is based on the discovery by Pauly and Munro (1984) that $\Phi$ ' values are very similar within related taxa. So, the growth performance comparisons were made using the growth performance index ( $\left.\Phi^{\prime}\right)$ which is preferred rather than using $L_{\infty}$ and $K$ individually (Pauly and Munro 1984) and is computed as:

$$
\Phi^{\prime}=\log (K)+2 \log \left(L_{\infty}\right) .
$$

\section{RESULTS}

Population Structure: A total of $340 \mathrm{H}$. pardalis and $300 H$. verrucosa were sampled between January and December 2018. The total length ranged between 4 and 19

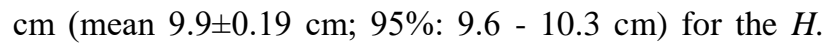
pardalis, and between 4 and $19 \mathrm{~cm}$ (mean $11.5 \pm 0.20,95 \%$ : $11.1-11.8 \mathrm{~cm}$ ) for the $H$. verrucosa. Mean total length of $H$. verrucosa was significantly greater than the $H$. pardalis mean total length (t test; $P<0.001$ ). Size-frequency distributions were significantly different between two species (Kolmogorov-Smirnov two-sample test; $\mathrm{d}=0.196$, $P<0.001)$. 
Age stracture and von Bertalanffy Growth Parameters: The seasonal and non-seasonal VBGF curves parameters obtained from the LFDA for each species are summarized in Table 1 . The $R n$ value of the non-seasonal growth curve for $H$. verrucosa did not improve when a seasonal growth curve was fitted (Table 1), suggesting that, at least for our data, $H$. verrucosa do not exhibit a seasonal growth pattern. This was also apparent in th results of the relative amplitude values of the seasonal oscillations $(C=$ 0.18 ) and in Figure 3B where no sinusoidal pattern could be observed in the seasonal von Bertalanffy growth curve. In $H$. pardalis, on the other hand, the $R n$ value of the nonseasonal VBGF curve improved by $36.18 \%$ after fitting the seasonal VBGF curve (Table 1). This result was also supported by the relative amplitude values of the seasonal oscillations $(C=0.90)$ and in Figure 4B where sinusoidal pattern could be observed in the seasonal VBGF curves for H. pardalis.

The slow growth period started at the begening of June for $H$. verrucosa ( $W P=0.43$; Figure 5). For $H$. pardalis, however, the start of slow growth period was at the end of February ( $W P=0.14$; Figure 5$)$. The calculated growth performance index $\left(\Phi^{\prime}\right.$; Table 1$)$ of seasonal growth for $H$. pardalis $\left(\Phi^{\prime}=2.511\right)$ was a bit greater than the $H$. verrucosa $\left(\Phi^{\prime}=2.445\right)$ growth performance indices (Table 1).
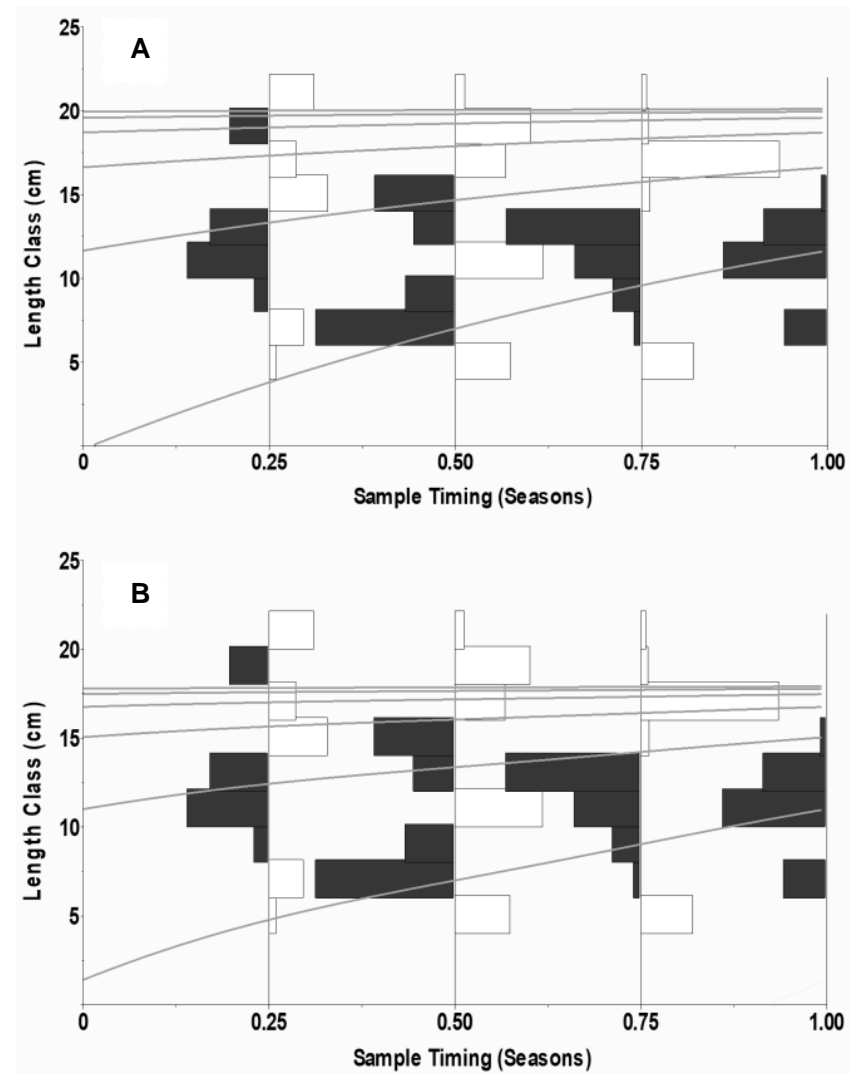

Figure 3. Length frequency distribution of Holothuria verrucosa with non- seasonal (A) and the Hoeing seasonal (B) von Bertalanffy growth function curves (lines) in the north Arabian Sea, Pakistan.
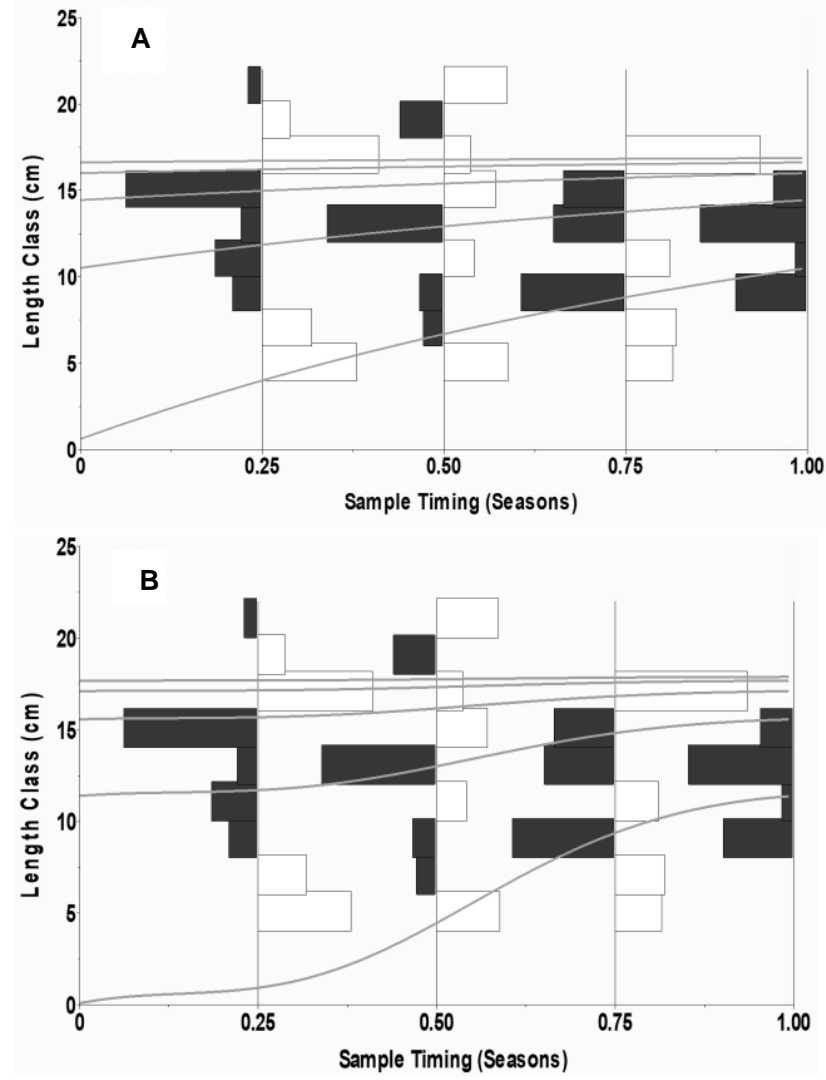

Figure 4. Length frequency distribution of Holothuria pardalis with non- seasonal (A) and the Hoeing seasonal (B) von Bertalanffy growth function curves (lines) in the north Arabian Sea, Pakistan.
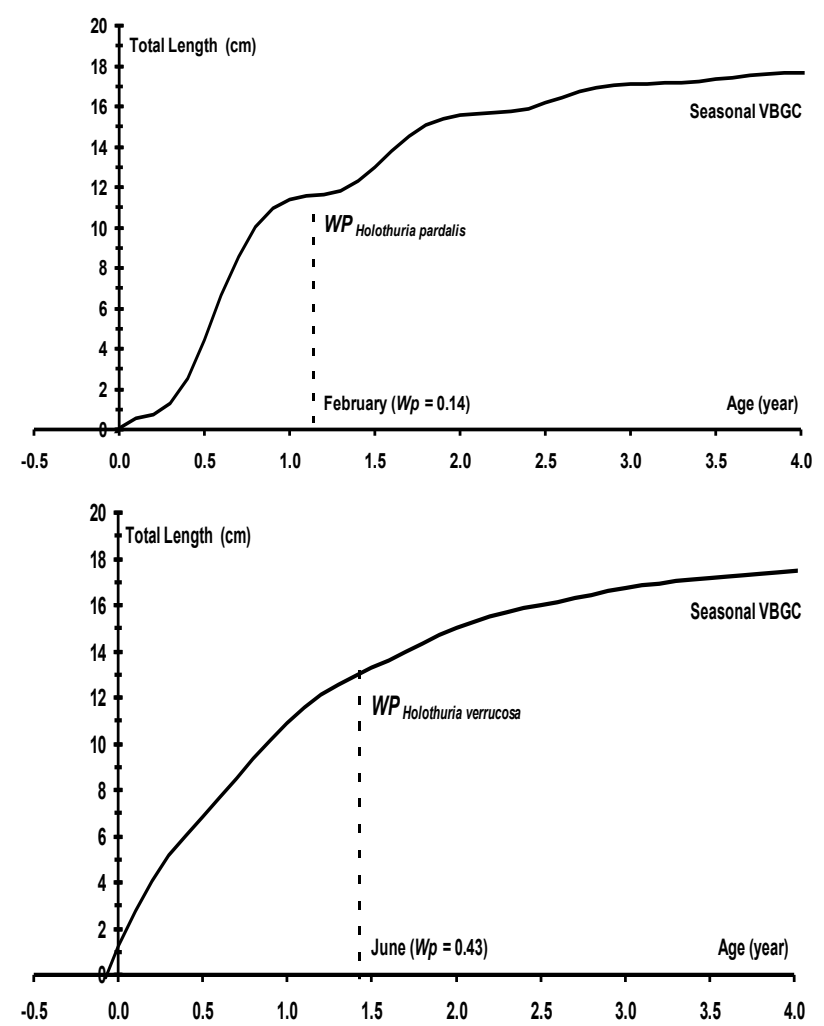

Figure 5. Winter point $(W p)$ of the seasonal oscillations in the seasonal von Bertalanffy growth function curves for Holothuria pardalis and Holothuria verrucosa in the north Arabian Sea, Pakistan. 
Table 1. Seasonal and non-seasonal von Bertalanffy growth function (VBGF) curves parameters estimated from the length frequency distribution analysis and maximum life span for Holothuria verrucosa and Holothuria pardalis. $L_{\infty}$, asymptotic total length $(\mathrm{cm}) ; K$, growth coefficient $\left(\right.$ year $\left.^{-1}\right) ; t_{0}$, age at zero length; $W P$, winter point; $C$, amplitude of growth oscillation; $R n$, goodness of fit index; $\Phi^{\prime}$, growth performance index.

\begin{tabular}{lcccc}
\hline \multirow{2}{*}{ Parameters } & \multicolumn{3}{c}{ Holothuria pardalis } & \multicolumn{2}{c}{ Holothuria verrucosa } \\
\cline { 2 - 5 } & Hoenig Seasonal & Non-Seasonal & Hoenig Seasonal & Non-Seasonal \\
\hline$L_{\infty}(\mathrm{cm})$ & 18.00 & 17.03 & 18.00 & 20.21 \\
$K\left(\right.$ year $\left.^{-1}\right)$ & 1.00 & 0.92 & 0.86 & 0.87 \\
$t_{0}($ year $)$ & -0.01 & -0.04 & -0.07 & -0.99 \\
$W P$ & 0.14 & - & 0.43 & - \\
$C$ & 0.90 & - & 0.18 & - \\
$R n$ & 0.489 & 0.485 & 0.286 & 0.210 \\
$\Phi^{\prime}$ & 2.511 & 2.426 & 2.445 & 2.551 \\
\hline
\end{tabular}

Estimated age - length key calculated from the seasonal VBGF curves parameters both $H$. pardalis and $H$. verrucosa individuals are showed in Figure 6. Length for the one year old class was estimated as $10.3 \pm 0.39 \mathrm{~cm}$ for $H$. verrucosa and $13.1 \pm 0.49 \mathrm{~cm}$ for $H$. pardalis by LFDA method. The calculated mean total length in the ages showed that the $H$. verrucosa individuals reached $68.9 \%$ of their maximum total length $\left(L_{\max }=19 \mathrm{~cm}\right)$ at the one year old class (mean: $10.3 \pm 0.39 \mathrm{~cm}$ ). For $H$. pardalis it was also calculated as $54.2 \%$. This fast growth characteristic of small individuals of these two species was also apparent in the growth curves in Figure 3-5, where it could be observed that the slight slope in the larger individuals compared to smaller sea cucumber leading to small individuals $(<$ mean 4.6-6.2 cm) grew more fastly than large ones.

Monthly growth rate of $H$. verrucosa was calculated as $0.52 \mathrm{~cm} /$ month for 0-365 days (0 age class), $0.57 \mathrm{~cm} /$ month 365 - 730 days (1 age class), 0.24 $\mathrm{cm} / \mathrm{month}$ for 730 - 1095 days ( 2 age class) by using estimated average total length values in the ages of $H$. verrucosa. For $H$. pardalis, however, it was calculated as $0.38 \mathrm{~cm} / \mathrm{month}$ for $0-365$ days ( 0 age class), $0.71 \mathrm{~cm} / \mathrm{month}$ 365 - 730 days ( 1 age class), $0.26 \mathrm{~cm} /$ month for 730 - 1095 days ( 2 age class). In older individuals ( $>2$ yars old), it almost tended to steady state for two species.

\section{DISCUSSION}

To the best of our knowledge this is the first study to calculate non-seasonal and the Hoenig seasonal VBGF curve parameters and age - length key of two holothurians, $H$. pardalis and $H$. verrucosa. When there is a seasonal growth pattern for holothurian species belonging to the same family in a geographical region, the estimations of $L_{\infty}$ and $K$ may differ significantly between the seasonal and non-seasonal models. The first function, the non-seasonal VBG model, provided realistic results. However, when seasonality was included (with the Hoenig model), more reliable values were obtained, which confirmed the seasonality in the growth of $H$. pardalis and $H$. verrucosa.
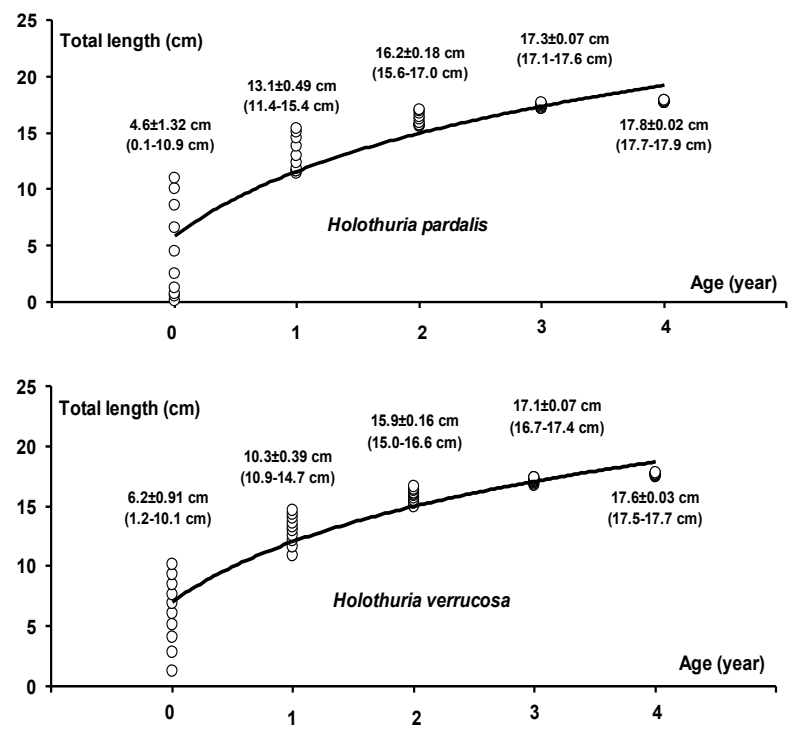

Figure 6. Length - age key (estimated length for each year class) from the seasonal von Bertalanffy growth function curves parameters both Holothuria pardalis and Holothuria verrucosa in the north Arabian Sea, Pakistan. Values as mean \pm stan. Err. (Min $-\operatorname{Max})$.

Our results including $L_{\infty}$ and $K$ obtained both seasonal and non-seasonal models showed that examined two sea cucumber have fast growth characteristics and also young and/or juvenile individuals (e.g. 0 and 1 years old) grow faster than olders. These mentioned growth rates for two species indicate that these species achieve asymptotic size quickly, even faster than other holothurians, such as Isostichopus badionotus ( $K=0.2)$, Isostichopus fuscus ( $K$ $=0.18)$, Stichopus vastus $(K=0.55)$, Stichopus quadrifasciatus $\left(K=0.34\right.$ year $\left.^{-1}\right)$, Holothuria arguinensis $\left(K=0.88\right.$ year $\left.^{-1}\right)$, Holothuria atra $\left(K=0.11\right.$ year $\left.^{-1}\right)$, Holothuria scabra $\left(K=0.52\right.$ year $\left.^{-1}\right)$ and Holothuria pulla $\left(K=0.24\right.$ year $\left.^{-1}\right)$ (Poot-Salazar et al., 2015; HerreroPérezrul et al., 1999; Sulardiono et al., 2012; Sulardiono \& Muskananfola, 2019; Olaya-Restrepo et al., 2018; Ebert, 1978; Pauly et al., 1993). Furthermore, the growth parameters $\left(L_{\infty}\right.$ and $K$ ) reported here for two holothurians are not similar to those reported for other species (Table 2) except for the $K$ values of $I$. badionotus $(K=0.70)$ and $H$. arguinensis $(K=0.88)$ in the family Stichopodidae and Holothuriidae. Growth differences among different populations of sea cucumber species have been attributed mainly to geographical variations (e.g. latitudinal variations, see: Herrero-Pérezru et al., 1999) (Table 2). These growth differences of the different sea cucumber species belonging to different family may not only be affected by latitude but also by other biotic (e.g. prey availability, predators, genetic variation) and abiotic factors (e.g. salinity, habitat structure). 
Table 2. Growth parameters of different sea cucumber species belonging to different family. $L_{\infty}$, asymptotic total length (cm); $K$, growth coefficient (year-1); $\Phi^{\prime}$, growth performance index.

\begin{tabular}{lllllll}
\hline Family & Species & $L_{\infty}(\mathrm{cm})$ & $K\left(\mathrm{yr}^{-1}\right)$ & $\Phi^{\prime}$ & Area & References \\
\hline \multirow{2}{*}{ Stichopodidae } & Isostichopus badionotus & 31.9 & 0.60 & 2.786 & Celestun, Mexico & 1 \\
& Isostichopus badionotus & 38.0 & 0.20 & 2.461 & Sisal, Mexico & 1 \\
& Isostichopus badionotus & 23.5 & 0.70 & 2.587 & Progreso, Mexico & 1 \\
& Isostichopus fuscus & 36.1 & 0.18 & 2.370 & Gulf of California, Mexico & 2 \\
Stichopodidae & Stichopus vastus & 31.6 & 0.55 & 2.739 & Karimunjawa, Indonesia & 3 \\
& Stichopus quadrifasciatus & 38.7 & 0.34 & 2.707 & Karimunjawa, Indonesia & 4 \\
Holothuriidae & Holothuria arguinensis & 66.9 & 0.88 & 3.595 & South Portugal & 5 \\
& Holothuria atra & 32.4 & 0.11 & 2.062 & Marshall Islands & 6 \\
& Holothuria scabra & 29 & 0.52 & 2.641 & Bolinao, Philippines & 7 \\
& Holothuria pulla & 30.7 & 0.24 & 2.354 & Bolinao, Philippines & 7 \\
\hline
\end{tabular}

1) Poot-Salazar et al., 2015; 2) Herrero- Pérezrul et al., 1999; 3) Sulardiono et al., 2012; 4) Sulardiono \& Muskananfola, 2019; 5: Olaya-Restrepo et al., 2018; 6) Elbert, 1978; 7) Pauly et al., 1993.

The $R n$ and $C$ values with visual growth curves (Figure 3B, 4B) evidenced that $H$. pardalis exhibited marked seasonality in growth than $H$. verrucosa. Seasonal growth pattern was also reported for different holothurians such as $H$. arguinensis from South Portugal (OlayaRestrepo et al., 2018) and Isostichopus badionotus off the northwest coast of Yucatan state, Mexico (Poot-Salazar et al.,2015), Isostichopus fuscus at Espiritu Santo Island, Gulf of California, Mexico (Herrero-Perezrul \& Reyes-Bonilla, 2008) and Cucumaria pseudocurata at Shell Beach, Sonoma County, California (USA) (Rutherford, 1973). Since there is no information on either seasonal or nonseasonal VBGF curve parameters for $H$. pardalis and $H$. verrucosa population along Karachi coast, Pakistan (northern Arabian Sea), we were unable to compare our findings with other studies. However, the major factors affecting the seasonal growth of marine organisms such as marine invertebrate were reported to be photoperiod, variation in water temperature and salinity fluctuating over the year, seasonal change in nutrient quality/availability, energy input into reproduction during the breeding season (Bilgin et al., 2009ab; Poot-Salazar et al., 2015; OlayaRestrepo et al., 2018). Unfortunately, detailed studies neither of productivity along the northern Arabian Sea coasts nor of the sea cucumber species reproduction biology such as maturation and spawning time, size at sexual maturity in these regions yet exists (except for the spawning time of $H$. arenicola). The coast of Pakistan is for most of the year influenced by high-salinity surface water (36 to $38 \mathrm{ppt}$ ) and the sea surface temperature (SST) during summer (May to September) is $28-30^{\circ} \mathrm{C}$ while during winter (November to February) it is $21-24^{\circ} \mathrm{C}$ and also rainfall $<150 \mathrm{~mm}$ annually (Siddique \& Ayub, 2015). Furthermore, there is variations in nutrient concentration in pre-monsoon (January to May), monsoon (June to August) and post-monsoon (September to December) due to fluctuations of rainfall. Such variations may also be related to productivity and availability of food and to the reproductive cycle and growth of sea cucumber species such as $H$. verrucosa and $H$. pardalis and others in the north Arabian Sea, Pakistan. The variations in the period of the WP known as slowest growth time generally related to environmental factors, physiological conditions of the marine animal, fullness of stomach and gonads stages (Bilgin et al., 2009a, 2009b; Ahmed et. al., 2016b, 2016b). The temperature also plays an important role in the reproductive events and the abundance of food and therefore it indirectly effective on the WP of the marine animals. As mentioned above, maturity and reproduction time based on gonad examination of the sea cucumber has not yet known along the northern Arabian Sea coasts (except for H. arenicola (Siddique \& Ayub, 2015)). But, the fluctuations of the condition index, which relaed to reproduction time have been reported for different sea cucumbers from these regions. For example, the seasonal variations in the mean condition factor $(C F)$ of different sea cucumber species such as Ohshimella ehrenbergii, $H$. arenicola, $H$. atra, $H$. pardalis and $H$. verrucosa was reported from the coasts of Karachi, Pakistan (Siddique et al., 2014; Ahmed et al., 2018a, 2018b) and the fluctuation of the gonad index $(G I)$ of these species deduced from the seasonal distribution of the condition factor as: higher during summer (monsoon) and lower during winter (postmonsoon). These GI fluctuation of the sea cucumbers are also compatible with the studies of Siddique \& Ayub (2015). Namely, the GI of $H$. arenicola was observed during spring and early summer, followed by a decrease in autumn and winter, which showed the spawning followed by resting phase. Moreover, the GI values were reported as a significant negative correlation with salinity and nonsignificant correlation with temperature (Siddique \& Ayub, 2015). The period of slowest growth for $H$. verrucosa corresponded to the monsoon when the highest $G I$ value occurs (i.e. June). The slowest growth period for $H$. pardalis, however, was estimated to be February, which is the period with a relatively low water temperature. Since the growth rate of holotorians depends on the effects of the climatic events (e.g. monsoon rain, temperature fluctions) 
on the food availability and quality of the habitat and also reproduction events, the slow growth of $H$. pardalis in winter may be the result of the extended both reproduction and poor nutrition periods due to high rainfall regime (lowers coastal seawater salinity) in monsoon and water temperatures.

In conclusion, seasonal growth was more pronounced in $H$. pardalis, probably due to the long spawning period and fluctuations of rainfall which decreased the productivity and availability of food and therefore caused individuals to grow seasonally. In $H$. verrucosa, growth was dictated by the climatic events rather than reproduction activity. The effects of the climatic events as monsoon rain and reproduction activities on growth should be studied in detail in order to provide data for holotorian fisheries management in the north Arabian Sea, Pakistan

\section{REFERENCES}

Ahmed, Q. \& Ali, Q.M. (2014). Abundance and distribution of Holothuroidea (Echinodermata) with emphasis on heavy metals accumulation in organism and its habitat, Project: Higher Education Commission of Pakistan, (Grant No. IPFP/HRD/HEC/1688).

Ahmed, Q., Ali, Q.M. \& Conand, C. (2016a). New Additions to the holothurian fauna of Pakistan: Holothuria verrucosa, Holothuria cinerascens and Ohshimella ehrenbergii. SPC Beche-de-mer Information Bulletin, \#36, 20-23.

Ahmed, Q., Bilgin, S. \& Bat, L. (2016b). Length based growth estimation of most commercially important scombridae from offshore water of Pakistan coast in the Arabian Sea. Turkish Journal of Fisheries and Aquatic Sciences, 16, 155-167. DOI: 10.4194/1303-2712-v16_1_16.

Ahmed, Q., Ali, Q.M. \& Bilgin, S. (2018a). Weightlength relationship of Sclerodactylidae sea cucumber, Ohshimella ehrenbergii (Selenka, 1868) (Echinodermata: Holothuroidea), from Karachi coast, Pakistan. SPC Beche-de-mer Information Bulletin, \#38, 79-80.

Ahmed, Q., Poot-Salazar, A., Ali, Q.M. \& Bat, L. (2018b). Seasonal variation in the length-weight relationships and condition factor of four commercially important sea cucumbers species from Karachi Coast- Northern Arabian Sea. Natural and Engineering Sciences, 3(3), 265 281. DOI: $10.28978 /$ nesciences.468667.

Ahmed, Q., Thandar, A.S. \& Ali, Q.M. (2020). Holothuria (Lessonothuria) insignis Ludwig, 1875 (formally resurrected from synonymy of $H$. pardalis Selenka, 1867) and Holothuria (Lessonothuria) lineata Ludwig, 1875 - new additions to the sea cucumber fauna of Pakistan, with a key to the subgenus Lessonothuria Deichmann (Echinodermata: Holothuroidea).
Zootaxa, 4767(2), 307-318. DOI: 10.11646/zootaxa.4767.2.6.

Bilgin, S., Özen, Ö. \& Samsun, O. (2009a). Sexual seasonal growth variation and reproduction biology of the rock pool prawn, Palaemon elegans (Decapoda: Palaemonidae) in the southern Black Sea. Scientia Marina, 73(2), 239-247. DOI: 10.3989/scimar.2009.73n2239.

Bilgin, S., Samsun, O. \& Özen, Ö. (2009b). Seasonal growth and reproduction biology of the Baltic prawn, Palaemon adspersus (Decapoda: Palaemonidae), in the southern Black Sea. Journal of the Marine Biological Association of the United Kingdom, 89(3), 509-519. DOI: $10.1017 / \mathrm{S} 0025315408003056$.

Ebert, T.A. (1978). Growth and size of the tropical sea cucumber Holothuria (Halodeima) atra Jaeger, at Eniwetok Atoll, Marshall Islands. Pacif Sci, 32, 183-191.

Hamano, T., Amio, M. \& Hayashi, K. (1989). Population dynamics of Stichopus japonicas Selenka (Holothuroidea, Echinodermata) in an intertidal zone and on the adjacent subtidal bottom with artificial reefs for Sargassum. Suisanzoshoku, 37, 179-186.

Herrero-Pérezrul, M.D., Reyes, H., García-Domínguez, F. \& Cintra-Buenrostro, C.E. (1999). Reproduction and growth of Isostichopus fuscus (Echinodermata: Holothuroidea) in the southern Gulf of California, México. Marine Biology, 135, 521-532.

Herrero-Pérezrul, M.D. \& Reyes-Bonilla, H. 2008. Weight-length relationship and relative condition of the holothurian Isostichopus fuscus at Espiritu Santo Island, Gulf of California, Mexico. International Journal of Tropical Biology, 56(3):273-280.

Hussaina, I., Spöck, G., Pilz, J. \& Yu, H.L. (2010). Spatio-temporal interpolation of precipitation during monsoon periods in Pakistan. Advances in Water Resources, 33(8), 880-886.

Kirkwood, G.P, Aukland, R. \& Zara, S.J. (2003). Software: Length Frequency Distribution Analysis (LFDA) Version 5.0. Marine Resources Assessment Group (MRAG) Ltd., London, UK.

Lane, D.J.W., Marsh, L.M., Spiegel, V. \& Rowe, F.W.E. (2000). Echinoderm fauna of the South China Sea: an inventory and analysis of distribution patterns. The Raffles Bulletin of Zoology, (Suppl. 8), 459493.

Moazzam, M. \& Moazzam, N. (2020). Annotated checklist of sea cucumbers from Pakistan with new records of Holothuria (Theelothuria) hamata (Pearson, 1913) and Stichopus herrmanni (Semper, 1868), SPC Beche-de-mer Information Bulletin, \#40, 32-39.

Olaya-Restrepo, J., Erzini, K. \& GonzálezWangüemert, M. (2018). Estimation of growth parameters for the exploited sea cucumber Holothuria arguinensis from South Portugal. 
Fishery Bulletin, 116, 1-8. DOI: 10.7755/FB.116.1.1

Pauly, D. \& Munro, J.L. (1984). Once more on the comparison of growth in fish and invertebrates. ICLARM Fishbyte, 2, 21.

Pauly, D, Sambilay, V. \& Opitz, S. (1993). Estimates of relative food consumption by fish and invertebrate populations required for modeling the Bolinao reef ecosystem, Philippines. In: Christensen, V. \& Pauly, D. (Ed), Trophic models of aquatic ecosystems. ICLARM Conf. Proc. 26., 236-251p, ICLARM, Manila, Philippines.

Pawson, D. (1976). Shallow-water sea cucumbers (Echinodermata: Holothuroidea) from Carrie Bow Cay, Belize. Proceedings of the Biological Society of Washington, 89, 369-382.

Poot-Salazar, A., Hernández-Flores, Á. \& Ardisson, P. (2015). Use of the SLW index to calculate growth function in the sea cucumber Isostichopus badionotus. Scientific Reports, 4, 5151. DOI: 10.1038/srep05151.

Purcell, SW. (2010). Managing Sea Cucumber Fisheries with an Ecosystem Approach to Managing Sea Cucumber Fisheries, FAO Fisheries and Aquaculture Technical Paper No. 520, Rome, FAO, 157p.

Purcell, S.W., Samyn Y. \& Conand, C. (2012). Commercially important sea cucumbers of the world. FAO species catalogue for fisheries purposes. No. 6. Rome: FAO, 150 p.

Rutherford, J.C. (1973). Reproduction, growth and mortality of the holothurian Cucumaria pseudocurata . Marine Biology, 22, 167-176. DOI: 10.1007/BF00391780

Siddique, S., Ayub, Z. \& Siddiqui, G. (2014). Lengthweight relationship and condition factor in Holothuria arenicola (Holothuroidea: Echinodermata) found on two rocky coasts of Karachi, Pakistan. Pakistan Journal of Marine Sciences, 23,(1 2), 51-63.

Siddique, S. \& Ayub, Z. (2015). Population dynamics and reproduction of Holothuria arenicola (Holothuroidea: Echinodermata) in coastal waters of Pakistan, North Arabian Sea. Journal of the Marine Biological Association of the United Kingdom, 95(6), 1245-1254. DOI: $10.1017 /$ S0025315415000041

Somers, I.F. (1988). On a seasonally oscillating growth function. Fishbyte, 6(1), 8-11.

Sulardiono, B., Prayitno, S.B. \& Hendrarto, I.B. (2012). The growth analysis of Stichopus vastus (Echinodermata: Stichopodidae) in Karimunjawa waters. Journal of Coastal Develpopment, 15(3), 315-323.

Sulardiono, B. \& Muskananfola, M.R. (2019). Growth and stock analysis of Stichopus quadrifasciatus (Echinoderm: Holothurians) in Karimunjawa waters, Central Java Province, Indonesia. International Journal of Applied Environmental Sciences, 14(1), 53-62.
Tahera, Q. \& Tirmizi, N.M. (1995). A new record of Holothuria (Thymiosycia) arenicola Semper, 1868 (Echinodermata: Holothuroidea) from Pakistan. Raffles Bulletin of Zoology, 43, 217220.

von Bertalanffy, L. (1938). A quantitative theory of organic growth (Inquires on growth laws II). Human Biology, 10, 181-213.

WoRMS. (2020). World Register of Marine Species. Available from https://www.marinespecies.org at VLIZ. Accessed 2020-05-13. https://doi.org/10.14284/170 